\title{
WIND FARMS IN POLAND - LEGAL AND LOCATION CONDITIONS. THE CASE OF MARGONIN WIND FARM
}

\author{
Grażyna Gawrońska, Krzysztof Gawroński, Karol Król, Katarzyna Gajecka
}

\begin{abstract}
Summary
The aim of the present work is to analyse the legal, organizational and location conditions of the wind farm in the Margonin municipality. The Margonin wind farm is the largest environmental investment project in Poland. Wind power plants have been located in two areas, covering an area of over $50 \mathrm{~km}^{2}$ each. The planning procedure was launched in 2007, and the first windmills started their operation in 2009. The investment project implementation procedure was conducted in accordance with the law that was in force at the time. The body conducting the administrative proceedings provided public participation in the process, and the comments submitted by the residents were fully taken into account. In addition, the investor, previously required to carry out the acoustic analysis of the investment project, has silenced some of the station on the basis of the results. Distances from buildings, as well as sites of nature conservation have been preserved. The launch of the largest wind farm in Poland contributed to the improvement of the material situation of the inhabitants of the Margonin municipality as well as the overall functioning of that municipality. Currently, the investor is still actively involved in maintaining the appropriate condition of technical infrastructure.
\end{abstract}

\section{Keywords}

renewable energy $\bullet$ wind energy $\bullet$ wind power plant $\bullet$ local planning $\bullet$ local development

\section{Introduction}

Renewable energy sources are such energy sources whose resources used to produce thermal, electric or mechanical energy do not decrease, or their renewal takes place in a short time [Hodana et al. 2012]. Renewable energy sources are sources that process the energy of: wind, sun (solar), Earth (geothermal), waves, currents and tides, river drop and energy obtained from biomass, landfill biogas, as well as from biogas created in sewage disposal or treatment processes or decomposition of stored plant and animal remains [Act 1997].

The application of modern technologies and the dynamic development of wind energy significantly increased the possibilities of obtaining wind energy in Poland. The development of the wind turbine market, adapted to low speed wind, contributed to 
this. Areas that have not been considered before for the location of wind farms due to lack of economic feasibility have now been given the opportunity, as they became suitable for investment projects of this kind [Wiśniewski et al. 2012]. The correctness of the wind farm location selection affects the efficiency and minimization of project costs. Both stable and labile factors, as well as changes in the surrounding environment, are taken into account, including those limitations that are hard to measure, and qualitative factors [Staliński 2016].

\section{Purpose and goals of the work}

The wind farm location process is a complex and time-consuming one. When making a decision on the location of a wind farm, it is necessary to calculate the costs necessary to start operations, and to define the market for the electricity that would thus be generated. Furthermore, the investor should take into account the risk resulting from the natural conditions occurring in a given location, and the resulting limitations [Budner 2003]. The legal conditions to the location, that remained in force until 2016, required obtaining many administrative decisions and permits, analyses of planning documents, and eco-physiographic studies - but despite these, location of wind farms was possible in many regions of Poland. The location procedure was to a large extent complicated by the provisions of the Act of 20 May 2016 on investment projects in the scope of wind farms [Act 2016]. The Act conditioned the location of the wind farm solely on the basis of the local zoning plan [Act 2003], and significantly increased the required distance between the wind farm and built-up areas. The aim of the present work is to analyse the legal, organizational and location conditions of the wind farm in the Margonin municipality.

\section{Material and methods}

The analytical and descriptive method was used in the work. The planning materials collected from the Margonin Municipality Office regarding the construction of the Margonin wind farm were analysed. The office provided, inter alia, a list of administrative decisions obtained by the municipality during the implementation of the project, an analysis of the advantages resulting from the location of the wind farm in the municipality, and the report on the impact of the planned project on the environment. The study includes legal changes that have occurred since the wind farm was started up. The analysis included planning materials, reports of the Polish Wind Energy Association from 2013 and 2015, industry studies devoted to technical issues of wind turbine installation and electric current generators as well as other data sources.

\section{Description of the studied area}

The Margonin municipality is located in the Wielkopolska region (Wielkopolskie voivodeship) in the Chodzież district (Fig. 1), $15 \mathrm{~km}$ from the main district town of Chodziez, and at a distance of $85 \mathrm{~km}$ from Poznań, which is the capital of the 
Wielkopolska region. It is a mixed, urban-rural municipality with an area of 122 $\mathrm{km}^{2}$. It is adjacent to the municipalities of Budzyń, Chodzież, Gołańcz, Szamocin and Wągrowiec, and is the third municipality in the district in terms of population.

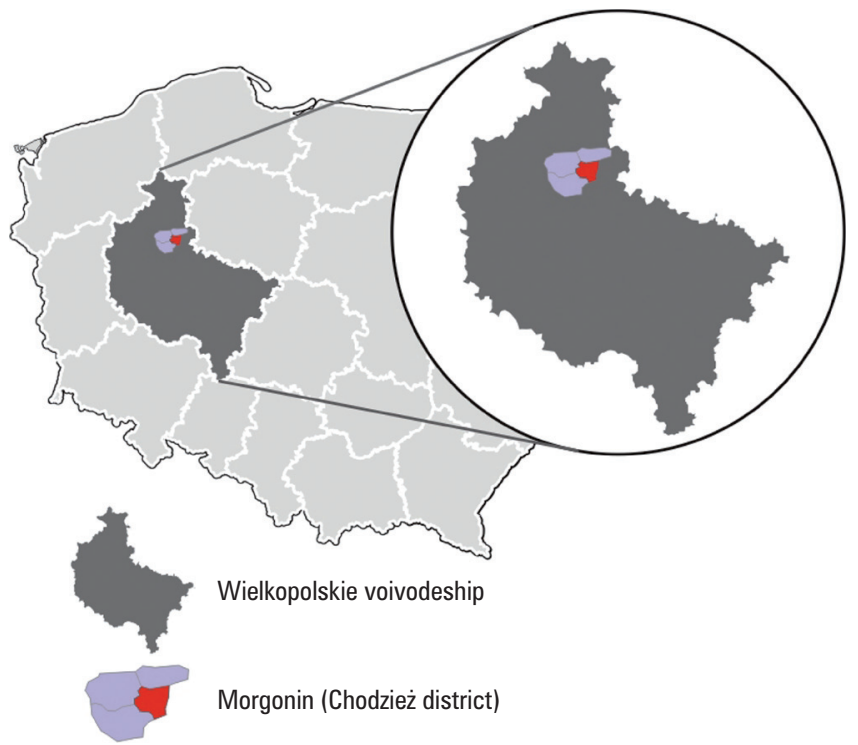

Source: Authors' own study

Fig. 1. The location of the Margonin municipality

The Margonin municipality is located within Pagórki Chodzieskie (Chodzież Hills), which are part of the Wysoczyzna Gnieźnieńska (Gniezno Upland) and the ToruńEberswald Pradolina (valley). Only a small area of the northern part of the municipality is located in the Odcinek Wyrzyski area. The picturesque moraine landscape is dominated by the moraine undulating plateau. The municipality has the largest lake in the district - Lake Margonińskie, covering an area of 215.4 ha. The highest elevation of the area reaches a height of $110 \mathrm{~m}$ above sea level.

The area of the Chodzież district was included in the European ecological network - Natura 2000 - on the basis of the Birds Directive. The area covers a variety of diverse habitats with riparian forests and a well-preserved meadow complex. Within the district, there are two Special Bird Protection Areas with a European rank. 18 different protected species have been found within its bounds. The nearest wind farm is located $10 \mathrm{~km}$ south of the Natura 2000 site.

From the north to the south of the municipality, along the Margoninka River and Margonińskie Lake, runs the border of the Protected Landscape Area of the Noteć Valley with an area of 72072 ha. The said area extends beyond the boundaries of the Margonin municipality. The landscape is dominated by meadows, bushes and tree 
stands. There are numerous drainage channels and ditches as well as oxbow lakes. These areas constitute habitats for water and marsh birds. The nearest wind farm from the Noteć Valley Protected Landscape Area is within $800 \mathrm{~m}$.

The Dolina Wełny and Rynna Gołaniecko-Wągrowiecka Protected Landscape Area includes within its bounds two ecological corridors: Rynna Gołaniecko-Wągrowiecka and Wełna River. They act as a connector and path of movement of individual specimens of different populations. They create conditions for the migration of plants and animals. The area is located $6 \mathrm{~km}$ from the Margonin wind farm.

\section{Procedure for the location of wind farms in Poland}

Currently, the aim is to increase the location capacities of wind farms in Poland. The area of their location should be free from infrastructural, environmental and economic constraints. The potential of wind energy is directly related to the spatial distribution of open areas (these are areas with low surface roughness, without objects that would disrupt the free flow of air); as well as to the development of win turbine production technology adapted to low speed winds.

The construction of a wind farm in Poland takes an average of 5 to 7 years, while the process of developing plans for the investment project can last from 3 to even 6 years. The factor significantly slowing down the design work is the complexity of administrative procedures, and varying interpretations of the existing legal provisions. The speed of the project implementation is directly related to the investor's financial liquidity and the size of the planned wind farm.

The investment location process can be divided into five different stages, the completion of which is necessary for the proper implementation of the investment project. The first stage concerns the location of the investment venture. The initial decision on the optimal location is based on the analysis of the possibility of obtaining space for the given development. This is related to the signing of preliminary agreements with the owners of land on which the wind farms and their accompanying infrastructure are to be located. Before proceeding to the formal and legal procedure, land must be acquired (bought) or leased. The land should meet the relevant criteria contained in the Act of 20 May 2016 on Wind Farm Investment [Act 2016]. Obtaining a legal title to the property for the construction of a wind farm starts the procedure of creating a wind farm. It is important that the legal title should cover more than just the plot on which the foundations for wind turbines will be located. We should also keep in mind the transmission infrastructure, transit stations, transformer stations and access roads. The running of the farm is not only its construction and operation, but also the maintenance and modernization works, and possible repairs if needed.

\section{Ownership (property right)}

Ownership of the real estate property gives the investor all rights to the specific property, and does not require obtaining additional legal titles. From the investor's point of 
view, this is the safest legal form that minimizes the risk associated with the possibility of losing the right to the real estate. In addition, in the event of the necessity to credit the investment, the ownership of the land gives the owner the possibility of securing a mortgage. On the other hand, obtaining ownership of real estate is not always economically justifiable. In the first phase of the investment, obtaining ownership may turn out to be risky. Suffice it that the environmental or planning conditions are not met, and the investment will require a change of location. Therefore, investors often decide to conclude civil law contracts, or obtain limited property rights instead.

\section{Tenancy contract, lease agreement, and usufruct}

Tenancy contract is the most popular form of obtaining a legal title to land properties designated for wind farms. The advantage of this form of ownership is the ability to influence the content of the contract, and the entry of the rights into land and mortgage records. This significantly reduces the risk of termination of the contract. In addition, the maximum duration of the tenancy contract allows long-term use of the property.

A direct leasing agreement is not a common way to obtain the right to real estate property. It is an alternative to the tenancy contract and the related issue of obtaining benefits. In the case of direct leasing, this problem does not exist, however, there is a need to pay remuneration to the owner, with the amount equal to the value of the property.

A limited property right, the usufruct, allows the investor to use the property and obtain benefits from it. A disadvantage here is the inalienability of usufruct, which in practice means that the user cannot transfer the right to the property to another person. The usufruct right requires the owner's declaration in the form of a notarial deed, and it may relate to a specific (limited) or indefinite (unlimited) use. In the situation of acquiring land for the investment project, which is the construction of a wind farm, the advantage is the establishment of use for a period covering the construction, operation and decommissioning of the farm.

\section{Transmission service easement}

The transmission service easement is a limited property right, which the investor uses in the event of having to obtain a legal title to the real estate through which the element of transmission infrastructure is to be conducted (cable, power line, pole, transformer station). The transmission service easement establishes the right to assemble equipment as well as to carry out maintenance work. This right does not explicitly specify the rules for the operation of devices, in particular the entry of rotor blades into the air space of a property burdened with the easement of transmission. In a situation where the owner of the real estate on which the element of transmission infrastructure is to be found does not agree to the conduct of such operations, or demands too high remuneration, the investor may refer the case to court. 


\section{Wind farms versus local plans}

The construction of a wind farm is most often based on the arrangements contained in local spatial development plans (zoning plans, MPZP). The adoption of a new Local Spatial Development Plan or the change of the existing one requires that the municipality preparing to implement the wind farm project adopts the study of conditions and directions of spatial development, developed obligatorily for the whole area of the municipality. The MPZP project should designate areas where devices generating electricity with a capacity of over $100 \mathrm{~kW}$ will be located, as well as buffer zones for the developed and built-up areas. The complete planning procedure should be carried out in a situation in which the Local Spatial Development Plan exists, but it does not provide for the possibility of building facilities for the use of renewable energy sources. The document should cover wind farm facilities and access roads. In addition, it should be flexible enough, so that no changes to the Local Spatial Development Plan should be necessary in the event of changes made by the investor. The local spatial development plan is the basis for issuing administrative decisions necessary for wind farm implementation, including decisions on environmental conditions and decisions on issuing building permits. The successful implementation of the investment project will depend on the correctly executed planning procedure.

Until recently, it was possible to locate wind farms based on the administrative decision on building conditions. According to the Act of 20 May 2016 on wind farm investment projects [Act 2016], the location of wind farms is possible only on the basis of the local spatial development plan (MPZP). In addition, in a situation in which there was no local spatial development plan in place, the investor had the opportunity to apply to the head of municipality or city mayor to issue a decision on determining the location of a public purpose investment project. Obtaining such decision was only possible for investment projects that constituted a public purpose. Nevertheless, devices that are used to generate electricity are not considered to be public-purpose investment projects. At this point, Polish law is incompatible with the Directive of Renewable Energy Sources [Directive 2009]. It should be noted, however, that such decisions were issued and were not questioned by administrative courts (or were questioned only in rare and exceptional cases).

The assessment of the environmental impact of a wind farm

The assessment of the project's environmental impact is an administrative procedure that is designed to assess the possible effect of the planned investment on the environment. The key element of the assessment is the analysis and verification of the report on the project's environmental impact, and ensuring public participation in the proceedings [Gawrońska and Policht 2014].

Regulation by the Council of Ministers of 9 November 2010 on projects that may significantly affect the environment [Regulation 2010] lists the following among projects that could potentially significantly affect the environment: installations that use wind energy with a total capacity of $100 \mathrm{MW}$ or more to generate electricity, instal- 
lations located in the maritime zone of the Republic of Poland, as well as installations with a total height greater than $30 \mathrm{~m}$, located in areas covered by various forms of nature protection. This means that such an investment may require an environmental impact assessment (if the competent authority determines that such a need exists), and therefore the investor needs to obtain a decision on environmental conditions in these proceedings.

The application for a decision on environmental conditions should concern not only the construction of wind turbines themselves, but also technical infrastructure. It is necessary to attach a project information card to the application for such a decision. The project information card is a document that defines the scale, type and location of the investment project, as well as the environmental protection measures envisaged by the investor.

The assessment of the project's environmental impact is binding for the investor. In principle, the most important aspect of the environmental assessment in the case of wind farm implementation is the acoustic impact. The problem of noise is one of the main causes of social conflicts during the wind farm's location procedure.

\section{Detailed analysis of location assumptions for the Margonin wind farm}

The first mention of the location of the wind farm in the Margonin municipality appeared already in the late 1990s. After 2007, the municipality proceeded to issue a location decision. On September 4, 2008, the inauguration of the construction work of the "Wind Power Plant Team in Margonin" was celebrated. From the point of view of the municipality, it was a very substantial undertaking. Prior to the construction, the investor (the Portuguese company EDP Renewables) initiated cooperation with the owners of 55 plots where the windmills were located. In addition, the accompanying infrastructure required collaboration with 70 residents of the town and municipality of Margonin.

Margonin municipality from the beginning focused on the benefits of the location of the wind farm. Budget revenues from the construction tax amounted to approximately PLN 3.3 million per year. There was also an increase in affluence of the residents of the municipality itself. The city authorities have focused on modernization, as well as the construction of municipal roads and the supplementation of technical infrastructure. Furthermore, the construction of the wind farm was used in the promotion of the municipality and the Chodzież district.

In Margonin municipality, 60 wind turbines were located, with a total capacity of $120 \mathrm{MW}$, which makes it possible to meet the energy needs of 90 thousand households. The farm was divided into two areas: (1) Margonin West Wind Farm - with 11 turbines and (2) Margonin East Wind Farm - with 49 turbines (Fig. 2). The power of each installed turbine is $2 \mathrm{MW}$. Turbines are mounted on steel towers with a height of $100 \mathrm{~m}$. Each wind turbine consists of a steel tower, a nacelle, and an impeller with a diameter of $90 \mathrm{~m}$. The foundation, which is the base for the assembly, consists of reinforced concrete beams in the shape of a square with side between $17.5 \mathrm{~m}$ and $19.0 \mathrm{~m}$, 
depending on surface and soil conditions. The foundation was recessed in the ground at the depth of 4 meters.

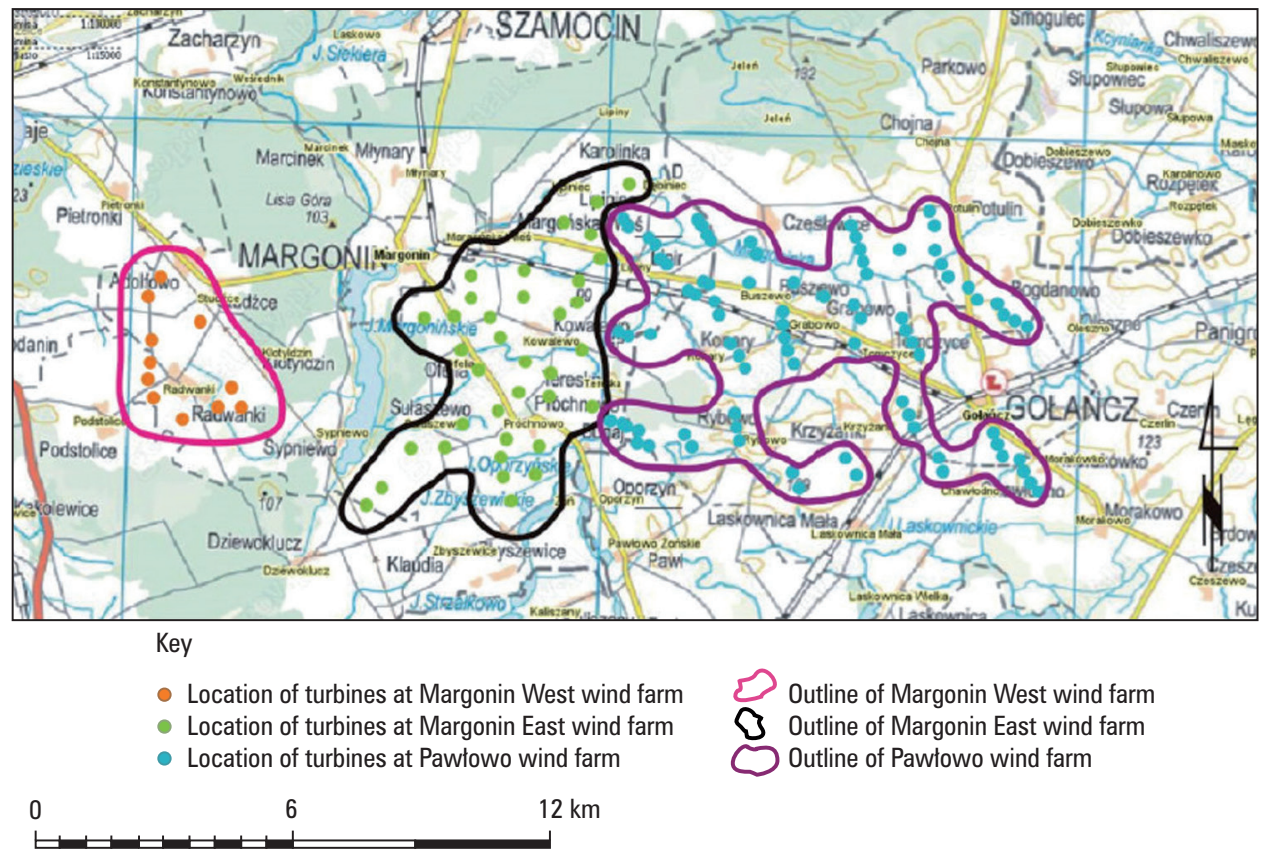

Source: Porzuczek [2019, p. 6]

Fig. 2. Location of wind turbines within the area of the Margonin wind farm (Chodziez district) and Pawłowo wind farm (Wagrowiec district, Gołancz municipality)

The operation of the wind farm is controlled and monitored by a computer system. All failures are recorded and signalled to the services responsible for the operation, maintenance and repairs. The total investment cost is approximately PLN 800 million (EUR 166 million). It should be noted that the investor applied here one of the most state-of-the-art, proven technologies currently used in the world.

The Margonin wind farm produces an average of 268.5 GWh of electricity every year. This facilitates the reduction of pollutant emissions into the air in the amount of over 215300 tons of $\mathrm{CO}_{2}$, which would otherwise be generated from a plant powered with solid fuels.

\section{Administrative process of constructing the wind farm in Margonin municipality}

The process of issuing permits and decisions for the construction of a wind farm began in 2007. Taking into account the applicable law, the bases for issuing decisions were: Act of April 27, 2001 Environmental Protection Law [Act 2001], Regulation of 
the Council of Ministers of 9 November 2004 on determining the types of projects that may significantly affect the environment and detailed conditions related to the project's eligibility for the preparation of the environmental impact report [Regulation 2004] as well as the Act of 27 March 2003 on spatial planning and development [Act 2003]. In the investment process, 24 administrative decisions were issued: 9 decisions on environmental conditions, 11 decisions on building and land development conditions and 4 decisions on establishing the location of a public-purpose investment. Seven decisions on environmental conditions concerned the construction of the wind turbines themselves, and two concerned transformer stations: the Main Reception Point (GPO) and the Main Supply Point (GPZ). The decisions regarding building and land development related to the location of wind farms with technical infrastructure, the main collection point, internal wiring connecting individual wind turbines with the transformer station, roads and assembly sites, as well as the wind measurement mast.

The body conducting the administrative proceedings ensured public participation in the process. In order to speed up the procedure of granting permits, municipality administrators were involved in providing information to residents. The report on the impact of the undertaking on the environment was made available to the local inhabitants. The scope of the report resulted from the then binding Act of 27 April 2001, Environmental Protection Law [Act 2001]. The results included in the report indicated no need to designate a limited use area around the wind farm. The assembled wind turbines have been recognized as safe, not a source of harmful substances, and not posing any other threat. Wind turbines were located in a typically agricultural space. Due to the lack of a local spatial development plan during the investment planning stage, it was assumed that the existing function of these areas would be preserved. In the event of the need arising to update the study, attention was paid to the provision, in the form of guidelines, to maintain a minimum distance of $500 \mathrm{~m}$ between the wind farm objects and housing areas. The greatest concerns were related to the location of wind turbines, as well as their appearance. A small group of residents entered their remarks about the wiring route. Protesting farmers did not hide their fears related primarily to the destruction of drainage, and the costs of its subsequent reconstruction. However, they received the investor's assurance that the land would ultimately be restored to the pre-investment state. Three residents protested against the construction of wind turbines in the vicinity of their property. Therefore, the investor decided to remove two objects despite the fact that environmental requirements were met.

During the deployment of individual wind turbines, the criteria determining optimal conditions were considered. The criterion of distance from housing areas was the basic factor conditioning the safety of residents. The possible occurrence of a construction accident was considered here, as well as the protection of people against excessive noise emitted by the wind turbines. Using the experience of other wind farms, it was indicated that depending on the equipment used, land cover forms, and tower height, the required distance is within $350 \mathrm{~m}-400 \mathrm{~m}$. For the purpose of selecting the correct location, dedicated computer software was used, noise emission in the neighbourhood 
was calculated for individual wind turbines, and total noise was added up. As the basis criterion, the provisions of the Regulation by the Minister of the Environment of 29 July 2004 on permissible noise levels in the environment were adopted and followed [Regulation 2004].

The wind farm project in the Margonin municipality took into account the mutual influence of wind turbines in its criteria. Each movement of the blades causes the wind to change from laminar to turbulent at a certain distance behind the wind turbine. Such a change may pose a threat to another wind turbine located at too close a distance. In order to avoid this phenomenon, correct densities of wind turbine placement have been maintained. Furthermore, the impact of the wind farm on the fauna, first of all on bird habitats, was also analysed.

The original design of the location of wind turbines in the Margonin municipality had been changed several times. After reviewing the criteria, the investor made the necessary corrections. Due to the high density of wind turbines within a small area, it was decided that several turbines needed to be moved. In addition, the area in question was characterized by the accumulation of noise emissions and exceeded the permissible noise level for housing development. Pursuant to the Regulation of the Minister of the Environment of December 23, 2004 on the requirements for the measurement of emission volumes [Regulation 2004], noise emission was assessed using the appropriate measurement and calculation methodology. The results of the analysis indicated the need to silence some of the turbines.

\section{Changes to the study of conditions and directions of local development for Margonin municipality pertaining to the wind farm}

The study of conditions and directions of spatial development is an instrument of spatial planning, obligatory for the municipality area within its administrative boundaries. The study does not constitute a local act of law, but it is binding for the municipality authorities when drawing up local plans. Such a document for the municipality of Margonin was developed in 1999.

The first change to the municipal study was passed by the Margonin Town and Municipality Council by virtue of Resolution No. XXI/215/05 of 28 September 2005. This change was the result of the introduction of new legal regulations in the field of planning and spatial development. The study took into account above all the conditions included in article 10 of the Act of 27 March 2003 on Spatial Planning and Development [Act 2003] regarding the current use, development, and utilities, as well as the principles of spatial order. It also included a provision referring directly to the acquisition of energy. Within the area of the Margonin municipality, it is allowed to generate electricity for the needs of business and for households from non-renewable energy sources, while maintaining the applicable provisions. This provision permits the existence of wind farms, whose location should be determined on the basis of detailed municipal regulations, taking into account the necessary elements of technical infrastructure, high voltage transmission lines, and transformer stations. 
The second change to the study was adopted by the Margonin Town and Municipality Council in the resolution No. IV/37/2015 of 29 January 2015, and it supplemented the study of conditions and directions of spatial development for the municipality of Margonin with specific arrangements applicable in one part of the municipality. The main purpose of the change was to provide for the construction of a $110 \mathrm{kV}$ high voltage power line, as well as the construction of the Main Power Point (GPZ). These elements constituted the equipment of the existing Margonin wind farm. The range covered by the change to the study included a strip of land with a width of $10 \mathrm{~m}$ to 20 $m$ on both sides of the planned linear element of the infrastructure, and a plot of 1 ha, intended for the construction of a transformer station (GPZ). The provision concerning the supply of electricity to the Margonin municipality allowed for the development of the power infrastructure network in the municipality. This applies to the expansion of the existing high and medium voltage networks, as well as the construction of new lines and additional Main Power Points (GPZ).

The current study on the conditions and directions of spatial development for the municipality of Margonin was adopted by Resolution No. VIII/87/2015 of the Margonin Town and Municipality Council of May 21, 2015. During work on the study [Study 2015] the guidelines included in the superior planning documents at the national, regional and district level were taken into account. In the chapter devoted to other problem areas, there is a provision regarding wind turbines in the Margonin municipality. It concerns the prohibition of construction development intended for permanent human habitation within the protection (buffer) zone with restrictions to construction development and land use. However, this prohibition does not apply to areas that are not subject to acoustic protection (within the meaning of specific provisions). The said provision should be further discussed in the local spatial development plans for the area of the wind farm itself. Furthermore, the recommendations include the need to ensure continuous technical control and monitoring of the electricity producing equipment, as well as the entire set of accompanying infrastructure devices. There are no plans to designate areas for the location of new wind turbines.

\section{Law (Act) on wind farm investment projects}

The Act of 20 May 2016 on wind farm investment projects [Act 2016], referred to as the "distance act", regulates the process of location and construction of wind farms. The Act increases the minimum distance from built-up areas in relation to the requirements prior to the adoption of the Act, which in practice may inhibit the development of the wind energy sector. A wind farm can be located at a distance of not less than 10 times its height (calculated including the rotor and the blades) from residential buildings and valuable natural areas. The distance thus defined must be taken into account by the competent authority during the preparation of: the study of conditions and directions for spatial development, the local spatial development plan, the regional spatial development plan, as well as administrative decisions on land development and building conditions, building permits, and decisions about environmental conditions. 
The local plan created for the needs of the wind farm should specify the total maximum height of that wind power plant. It should also be prepared for the area where new construction objects intended for permanent human habitation cannot be located. The boundaries of the plan area are determined based on the maximum total height of the wind power plant. Information on the height of the wind turbines is attached to the draft resolution on launching the preparation of the Local Development Plan for the needs of the wind farm location.

Pursuant to the Act of 20 May 2016 on wind farm investment projects [Act 2016], it is not possible to expand wind turbines that are already in existence and do not meet the distance criterion. In this case, the Act only allows the execution of maintenance works, and taking actions allowing the proper operation of the wind turbines. According to the research conducted by Ambiens environmental consultancy for investment processes [Kaczerwoski 2016], the Act limited the implementation of $99.2 \%$ of projects. The study used 124 forms, each of them related to a separate investment project. The remaining $0.8 \%$ of the projects meet the distance assumptions, however, these are small investment projects, between 1 and 3 wind turbines. The areas where the majority of these investment projects are located do not have local zoning or local development plans. Furthermore, $75 \%$ of the projects that had been subjected to analysis concerned wind turbines located about $450-650 \mathrm{~m}$ from built-up areas. The remaining ones were located at a distance of 650-1000 $\mathrm{m}$ from the nearest development, and in the case of two investment projects, at a distance of $1050 \mathrm{~m}$. Current regulations regarding the distance are closely related to the height of the fitted wind turbines. Investigating the distances of the designed farms in connection with the height of the wind turbines used therein, it was found that $50.8 \%$ of projects would be located at a distance less than or equal to 3 times the windmill height, whereas $87.9 \%$ of investments would be located at a distance less than or equal to 5 times the windmill height. Currently, only one out of the 124 projects would meet the applicable standards. Wind farms, for which building permits have been obtained prior to the introduction of the changes in question, may be located without taking into account the distance criterion.

\section{Conclusions}

Conditions for the development of wind farms in Poland are comparable to those in other European countries, where the energy obtained from the use of wind power constitutes a much higher share in the total energy production. The environmental factors, spatial factors, political factors, legal and administrative factors, as well as technical and technological factors are important for the correct location of the wind farms. These factors determine the development of a wind farm in a given area, whereas each such investment project can significantly affect the environment.

The local community plays a very important part in the planning and spatial location of wind farms. This indicator is difficult to measure, and it often causes delays in project implementation. Such state of affairs is mainly caused by insufficient information flow between the investor and the residents. The solution to this problem was indirectly 
regulated by changes in the scope of legislation pertaining to renewable energy sources and wind farms. The Act on wind farm investment projects imposes the location of a wind farm solely on the basis of a local spatial development plan, for the area that is appropriate for the location of the project. The advantage of these legal regulations is the significant public participation from the very beginning of the investment project.

The wind farm location process is a complex one, and the completion of each stage is necessary for the proper implementation of the entire investment project. Choosing a location in space starts the procedure. The correct decision about the initial location is based on the signing of preliminary agreements with landowners, on whose land the wind turbines are meant to be located. The next stages constitute a complicated administrative procedure consisting in obtaining appropriate permits and decisions by the investor. The most important documents, which are binding for the investor, include the local zoning plan, the decision on the location of the public purpose investment project, and in the scope of environmental protection: administrative assessment of the environmental impact, and assessment of the environmental impact of the wind farm (as well as obtaining decisions on environmental conditions in these proceedings).

Many regulations in this area are included in the study of conditions and directions of spatial development of the municipality, and in relation to the Margonin wind farm, this was subject to many changes. Initially, the Act of 27 March 2003 on spatial planning and development contributed to the changes in the study. Wind farms are allowed in the municipality, the location of which should be determined on the basis of detailed municipal regulations. The purpose of the next change was only the extension of the existing wind farm, to include high voltage lines and the Main Power Point. The current study sets a buffer zone with a restriction in the construction, development, and land. There are no plans to designate areas for the location of new wind turbines. It is forbidden to carry out works that would result in increased noise levels, increased blade size or increased height of wind turbine towers.

The changes in Polish law regarding wind farms condition the location of wind farms solely on the basis of local spatial development plans [Act 2016], which was not yet required during the wind farm in the Margonin municipality. The investment project in question was implemented on the basis of a decision on land development and building conditions.

Wind farms constitute ventures that can significantly affect the environment. According to the provisions of the Act of 3 October 2008 on access to information about the environment and its protection, public participation in environmental protection, and environmental impact assessments [Act 2008], such undertakings are bound to obtain a decision on environmental conditions under which they may be subjected to the procedure of the assessment of the project's impact on the environment. The process of locating a wind farm is then carried out with the participation of the public. There should be a wide educational and information campaign for residents directly affected by the construction of a wind farm. In such case, the public consultations carried out will make it possible to minimize the risk of investment suspension. 
The launch of the largest wind farm in Poland contributed to the improvement of the material situation of the inhabitants of the Margonin municipality as well as the functioning of the municipality as such. Currently, the investor is still actively involved in maintaining the appropriate technical condition of the infrastructure.

The question of the location of wind farms involves many problems concerning various scientific disciplines. The impact of turbines should always be thoroughly tested. Municipalities, which are the main decision makers in the area of wind farms, should make every effort to properly consider each planned investment project, aiming above all for the safety of the people and the environment as well as proper and correct spatial development.

The development of modern wind turbines increases the options of employing them in the areas of central and southern Poland, which belong to a favourable and relatively favourable wind energy zones in Poland.

\section{References}

Act 1997. Ustawa z dnia 10 kwietnia 1997 r. - Prawo energetyczne (Dz. U. z 1997 r. Nr 54, poz. 348).

Act 2001. Ustawa z dnia 27 kwietnia 2001 r. - Prawo ochrony środowiska (Dz. U. z 2018 r., poz. 799).

Act 2003. Ustawa z dnia 27 marca 2003 r. o planowaniu i zagospodarowaniu przestrzennym (Dz. U. z 2003 r. Nr 80, poz. 717).

Act 2008. Ustawa z dnia 3 października 2008 r. o udostępnianiu informacji o środowisku i jego ochronie, udziale społeczeństwa w ochronie środowiska oraz o ocenach oddziaływania na środowisko (Dz. U. z 2017 r., poz. 1227).

Act 2016. Ustawa z dnia 20 maja 2016 r. o inwestycjach w zakresie elektrowni wiatrowych (Dz. U. z 2016 r., poz. 961).

Budner W. 2003. Lokalizacja przedsiębiorstw. Wydawnictwo Akademii Ekonomicznej w Poznaniu, Poznań.

Directive 2009. Dyrektywa Parlamentu Europejskiego i Rady 2009/28/WE z dnia 23 kwietnia 2009 r. w sprawie promowania stosowania energii ze źródeł odnawialnych (Dz. Urz. UE, L140/16, 5.6.2009).

Gawrońska G., Policht-Latawiec A. 2014. Ocena procedury wydawania decyzji o środowiskowych uwarunkowaniach z udziałem społeczeństwa. Acta Sci. Pol., ser. Formatio Circumiectus, 13(1), 31-44.

Hodana M., Holtzer G., Kalandyk K., Szymańska A., Szymański B., Żymankowska-Kumon S. 2012. Odnawialne źródła energii. Poradnik. Stowarzyszenie na rzecz efektywności energetycznej i rozwoju odnawialnych źródeł energii „Helios”, Kraków.

Kaczerwoski M. 2016. Ustawa odległościowa vs. development. Ambiens. Doradztwo środowiskowe w procesach inwestycyjnych. https://goo.gl/2hgNWK (accessed: 05.04.2019).

Porzuczek M. 2019. Projekt: farma wiatrowa Margonin Polska. EDP Renovaveis. https://goo. gl/1haugQ (accessed: 05.04.2019).

Regulation 2004. Rozporządzenie Rady Ministrów z dnia 9 listopada 2004 r. w sprawie określenia rodzajów przedsięwzięć mogących znacząco oddziaływać na środowisko oraz szcze- 
gółowych uwarunkowań związanych z kwalifikowaniem przedsięwzięcia do sporządzenia raportu o oddziaływaniu na środowisko (Dz. U. z 2004 r. Nr 257, poz. 2573).

Regulation 2010. Rozporządzenie Rady Ministrów z dnia 9 listopada 2010 r. w sprawie przedsięwzięć mogących znacząco oddziaływać na środowisko (Dz. U. z 2010 r. Nr 213, poz. 1397).

Staliński A. 2016. Lokalizacja farm wiatrowych w Polsce. Energia Gigawat, 10, Uniwersytet Ekonomiczny w Poznaniu, Poznań.

Study 2015. Studium uwarunkowań i kierunków zagospodarowania przestrzennego gminy Margonin - Załącznik Nr 1 do uchwały Nr VIII/87/2015 Rady Miasta i Gminy Margonin z dnia 21 maja $2015 \mathrm{r}$.

Wiśniewski G., Michałowska-Knap K., Koć S. 2012. Energetyka wiatrowa - stan aktualny i perspektywy rozwoju w Polsce. Instytut Energetyki Odnawialnej, Warszawa.

Dr inż. Grażyna Gawrońska

Uniwersytet Rolniczy w Krakowie

Katedra Melioracji i Kształtowania Środowiska

30-059 Kraków, al. Mickiewicza 24/28

e-mail: grazyna.gawronska@urk.edu.pl

ORCID: https://orcid.org/0000-0001-8816-1367

Prof. dr hab. inż. Krzysztof Gawroński

Uniwersytet Rolniczy w Krakowie

Katedra Gospodarki Przestrzennej i Architektury Krajobrazu

30-198 Kraków, ul. Balicka 253c

e-mail: krzysztof.gawronski@urk.edu.pl

ORICD: https://orcid.org/0000-0002-9922-7373

Dr inż. Karol Król

Uniwersytet Rolniczy w Krakowie

Katedra Gospodarki Przestrzennej i Architektury Krajobrazu

30-059 Kraków, al. Mickiewicza 24/28

e-mail:k.krol@onet.com.pl

website: http://homeproject.pl

ORICD: https://orcid.org/0000-0003-0534-8471

Katarzyna Gajecka

Uniwersytet Rolniczy w Krakowie

Katedra Melioracji i Kształtowania Środowiska

30-059 Kraków, al. Mickiewicza 24/28 